\title{
Curricular Tracking and Social Inequality in Mathematics Achievement: A Comparative Reform Study
}

\author{
Herman G. van de Werfhorst \\ University of Amsterdam \\ Correspondence: H.G.vandeWerfhorst@uva.nl
}

January 2017

\begin{abstract}
Between-school segregation is high on the agenda of academic researchers and policy makers. Especially between-school tracking is heavily debated, as early tracking is said to enhance social inequalities in learning opportunities.

Contemporary debates on the relevance of comprehensive education in the United States, the Netherlands, Belgium, England and Germany, may learn from changes in educational inequalities that have emerged after past reforms from early tracking to comprehensive systems. We study educational inequalities by socioeconomic background in nine countries, across time. Using a comparative reform study and international student assessment data collected among eigthgraders, it is demonstrated that social inequalities more strongly reduced in systems that have transformed their educational system from tracked to comprehensive education than in systems without this reform.
\end{abstract}




\section{Curricular Tracking and Social Inequality in Mathematics Achievement: A Comparative Reform Study}

\section{INTRODUCTION}

Many studies have shown that the age and form of curricular tracking in a society's educational system are related to the level of inequality of educational opportunity by social and ethnic background (e.g. Brunello and Checchi 2007; Cobb-Clark et al. 2012; Dronkers et al. 2012; DuruBellat and Suchaut 2005; Hanushek and Wössmann 2011; Horn 2009; Jackson et al. 2012; Lavrijsen and Nicaise 2015; Marks 2005; Pfeffer 2008; Ruhose and Schwerdt 2016; Schütz et al. 2008; Van de Werfhorst and Mijs 2010). In countries where the selection of students in different tracks happens earlier, and more rigidly in separate schools offering different programmes, the association between socioeconomic background and academic achievement tends to be stronger than in societies with a comprehensive secondary school system. Also, tracking increases the dispersion of student performance (Montt 2011; Hanushek and Wössmann 2005), and channels further educational expectations (Buchmann and Park 2009; Parker et al. 2016).

The issue of early versus later tracking is highly urgent today, as reforms have been suggested in various countries, either to postpone tracking (Flanders in Belgium, the Netherlands, Germany), or to reform back to an early-tracked system with the restored grammar schools in England and Wales. Also in the United States the situation of the public schools is urgent with the new Trump Administration, and for the American debates it is important to know more about how comprehensive, inclusive forms of education as opposed to highly segregated systems are associated to social inequities in learning.

While the comparative evidence on tracking effects on inequality in student achievement is based on cross-sectional research that compares societies at one point in time, it is important to 
know whether reforms towards later tracking have reduced inequalities by social background. Cross-sectional comparative designs suffer from the problem that countries differ in many different ways, making it difficult to isolate the effect of tracking institutions from other country characteristics that may be correlated with tracking. Existing reform studies, by contrast, focus on single countries (Dronkers 1993; Duru-Bellat and Kieffer 2000; Gamoran 1996; Gamoran and Weinstein 1998; Le Donné 2014a; Meghir and Palme 2005; Pekkarinen et al. 2009), but revealed trends could just reflect broader trends found in other countries as well.

To know more about tracking age reforms in relation to inequalities in educational outcomes by social background, an important analytical step ahead is a comparative reform design. Such a design bridges the two approaches of comparative and dynamic studies of tracking effects. The approach is comparative, but what is compared across countries is how inequalities change between two moments in time, in countries with comprehensive reforms and those without. Several comprehensive reforms have taken place in the 1960s and 1970s (Leschinsky and Mayer 1990), and the current debates may learn from the recent educational history in this regard. The comparative reform design avoids studying one country in which changes in inequalities could reflect broader trends across societies. And it avoids that cross-sectional differences related to tracking age are automatically interpreted as tracking effects, as one would want to know whether within-country changes also support such a conclusion. In other words, if there were tracking effects on inequality of opportunity, one would expect that socioeconomic differences in achievement would decrease in countries that have postponed the moment of selection in their systems, relative to countries that have not done so.

We employ a difference-in-difference design on mathematics achievement using nine countries. Educational reforms are examined on the age of selection, that have taken place in four countries. By comparing the difference in inequality by social origin between student assessments of different cohorts, who get 'treated' in different ways depending on the educational system they 
enrolled in with regard to age of selection, it can be assessed to what extent the difference in inequality between periods differs between reform and non-reform countries. Eighth-graders are compared of the First International Mathematics Study (FIMS) of 1964 (pre-reform) the Second International Mathematics Study (SIMS) of 1980-1982, and the Third International Mathematics and Science Study (TIMSS) of 1995.

Moreover, inequality of educational opportunity, which in this study is measured by the association between socioeconomic background and student test scores, is studied in the context of possible gains in terms of average achievement that may be associated to early tracking. A so-called 'trade off between equality and efficiency' could emerge when larger inequalities coincide with higher average performance of students (Hanushek \& Wössmann 2005; Van de Werfhorst \& Mijs 2010). Particularly in the context of educational reforms such a trade-off could easily develop, as reforms towards comprehensive education may create a 'shock' to the educational system which may reduce average performance in the short run.

Another weakness of earlier studies is that they mostly examine changes in the average attainment, and differences in average attainment between groups. We study the trade-off between equality of opportunity and efficiency for different parts of the achievement distribution: low achievers, medium achievers, and high achievers. This is highly relevant because tracking is particularly said to harm the high achievers, suggesting that the potential costs of equity are most severe for this group.

The results indicate that inequalities have reduced in systems that have reformed their educational system towards a comprehensive, generic high school system in the heydays of educational reform. However, we find that smaller inequalities may come at a cost: the achievement level declined in reformed systems relative to unreformed systems, particularly at the middle and bottom of the performance distribution. Equality of opportunity does not seem to harm the highperformers much. 


\section{PAST TRACKING AGE REFORMS AND THEIR RELATION TO SOCIAL INEQUALITIES}

During the second half of the 20th century, and especially in the 1960s and 1970s, a number of educational systems have been reformed from a tracked to a comprehensive system. From this period we may learn in assessing the potentialities of currently debated policy reforms concerning the age of tracking in Belgium, England, the Netherlands and Germany.

Post-war politics has been strongly influenced by the social-democratic agenda, with a strong orientation towards the improvement of equality. Egalitarian politics of social-democratic and Christian democratic parties led to a growth of welfare state arrangements. Parties originally finding its constituents among working classes found more support among the middle classes too. Policies to enhance educational opportunities were part and parcel of post-war politics. Educational reforms were implemented in many countries, but not in all countries, even among those with an emerging egalitarian agenda.

In the late 1970s two Scottish government committees have recommended reforms to dismantle the highly stratified educational system, enabling that a 'wider variety of students would engage in a broader spectrum of subjects through emphasis on a common core' (Gamoran 1996: 23; Willms 1986). Using a pre- and post-reform design Gamoran (1996) showed that inequality by social background declined in Scotland, and the average achievement rose.

The Swedish government made plans for comprehensive reform already in the late 1940s, although it lasted until the early 1960s before a comprehensive system was fully installed for children aged 7-16 (Erikson and Jonsson 1996). Again using a pre-and post-reform design Meghir and Palme (2005) studied the impact of the reform on educational attainment and earnings, and found large effects. Moreover effects were strongest for children of low-educated backgrounds, pointing to a reduction in social inequalities as well. 
A similar reform from a two-track secondary school system to a nine to ten-year compulsory education was implemented in other Scandinavian countries; Norway in the 1960s and Finland in the 1970s. For Finland, Pekkarinen et al. (2009) studied the reforms in a similar design as Meghir and Palme (2005), and similar to our study. Comparing reformed and unreformed Finnish regions, the decline in inequality was larger if comprehensive reforms had been implemented than if regions still had a tracked system.

The French educational system has been reformed in the end of the 1970 s, carried out by minister René Haby. The Haby-reform abolished the distinction between the collèges d'education générale (CED) and colleges d'enseignement secondaire (CES), which were all placed under the general middle school in collèges serving students aged 12-16 (Prost 1990; Duru-Bellat and Mingat 1990). Using multiple cohort data and studying long-term trends in inequalities of educational opportunity, Duru-Bellat and Kieffer (2000) found declining inequality in the lower secondary colleges, but also showed that inequalities had moved to later stages in the school career.

In England and Wales the Secretary of State for Education and Science Anthony Crosland issued the "10/65 Circular", which tried to enforce the comprehensive reform to secondary schools by restricting funding to schools that retained selection. Between 1965 and 1975 around 90 percent of English schools became fully comprehensive, and virtually all schools in Wales. Generally British scholars find that the comprehensive schools implemented in England and Wales have not improved social mobility (Halsey et al. 1980; Heath 1990). Or, in the words Boliver and Swift (2011: 89): "comprehensive schools were as good for mobility as the selective schools they replaced".

The Netherlands also reformed its educational system in the 1960s, but a stratified system of secondary education was kept in place. However, opportunities improved to move from one track to another, and to stack different types of education, which avoided the vocational tracks to be de jure dead-end streets. Dronkers (1993) showed that the reform did not alter inequalities within the Dutch secondary educational system, suggesting that the policies to enable students to move 
between tracks is not sufficient to decrease inequalities. In the 1970s plans existed originating from Christian democrats and social-democrats to install a fully comprehensive middle-school system, but that plan never took full shape due to lack of political support (Greveling et al. 2015). Instead, a compromised basic education ("basisvorming") was implemented in secondary schools, in which general targets were determined which had to be taught in all school types (but at different paces). The parliamentary committee for the evaluation of school reforms chaired by Jeroen Dijsselbloem concluded in 2008 that the basic education policy had failed.

Similar to the situation in the Netherlands, Belgian education has been reformed in the 1960s and 1970s, but a stratified educational system was kept in place (cf. Van Houtte and Stevens 2009). Poland did recently reform its educational system and replaced an early tracking system fully with longer comprehensive education. In contrast to most earlier reforms in Europe, this reform of 2000 was implemented fast, and across the nation. Le Donné (2014a) used a pre- and post-reform design to study the impact of the reform on inequality of opportunity using the PISA data of 2000 and 2003. That study showed a marked decline in inequalities by socioeconomic background in Poland.

A recent policy has been proposed in the Dutch-speaking part of Belgium to postpone the moment of selection, but the implementation of the policies are, similar to the earlier in the Netherlands, a weak surrogate of the original plan to remove early tracking. It is too early to investigate the effects of this reform.

\section{THEORY: WHY IS EARLY TRACKING RELATED TO INEQUALITY IN STUDENT ACHIEVEMENT?}

Existing studies on macro-level tracking effects on inequality have been rather implicit on the question why early tracking in related to inequality of educational opportunity. In order to explain this relationship, we have to bridge two separate theoretical developments that have emerged in the educational stratification literature in the past two decades: macro-oriented comparative 
stratification studies on institutional effects, and micro-level theories on educational decision making. Bridging these two literatures is important, because comparative research has not been specific about the micro-level processes underlying institutional effects, and the educational decision making literature has not paid much attention to the institutional environment within which families have to make decisions.

If we want to understand how institutions affect inequalities, the starting point of our multilevel theory of educational inequality is that inequalities are produced by social action of individuals, including students and parents. Their actions are guided by the options they face, the costs and benefits associated to different educational careers, and the probability of success they believe to have in completing educational careers (Breen and Goldthorpe 1997). Moreover, educational careers are known to be the result of choices and opportunities children face at different branching points. At each branching point, children (and their parents) decide, for instance, whether to continue or drop out, or whether to enrol the academic route or the vocational route. Across the various stages of the educational career, students learn about further opportunities and current performance, both of which are important pieces of information on which basis families navigate through the educational system. Families make educational decisions based on current performance, and aspirations concerning final educational attainment.

However, students differ in the resources that help them to make informed decisions about the future. As Lucas (2001) argued, students of different social or racial/ethnic backgrounds are likely to vary with regard to the far-sightedness of their decisions at earlier branching points in the educational career. Students with fewer educational resources are more 'myopic' than students of more advantaged social backgrounds, implying that educational decisions are less strongly based on future aspirations but more on current performance. This could be the case because well-educated parents can better inform their children about the benefits associated to education, and the feasibility of completing higher levels of schooling. Also, as Morgan (2005) argued, students with 
fewer resources not only have less information, but also less reliable information about the different educational options, because the information they get from their social network is more diverse, and therefore more 'noisy'.

The educational institutional structure is important for inequalities because myopia is likely to become a larger problem if important decisions are made earlier in the school career. If the choice for a type of education has to be made at the age of 10 or 12, myopic children will have a larger information disadvantage than if selection takes place later. There is a longer school career lying ahead, with a larger number of potential decisions on which an information disadvantage exists compared to far-sighted decision makers. In comprehensive educational systems, by contrast, there are few choices to make in the early school career for which information differentials could be important. Moreover, according to the life course hypothesis (Blossfeld and Shavit 1993) parents are more important agents in children's educational choices at earlier life phases than at later ones. So even if children in early-selecting systems are fully informed about their own performance and probabilities of success of future options, their parents may lack information about the costs and benefits of future educational options, and their information level is relatively important in early educational decisions. Tracking systems therefore create opportunities for status competition in which elites are better able to navigate their children through the school system (Lucas 2001; Kelly and Price 2011).

An important implication of this line of reasoning is that educational inequality is not only produced by social differences in abilities, information quality and aspirations, but also by the structural opportunities students face after they have made educational decisions during the school career. If crucial decisions have to be made early, it could easily happen that disadvantaged students of reasonably high performance enrol in lower tracks, where they get educated at a less demanding level, which, as a self-fulfilling prophecy, further decreases their opportunities for more 
prolonged school careers. Students coming from more advantaged social backgrounds are likely to enrol in higher tracks, where more opportunities exist to proceed to higher levels of education.

What does this imply for inequality in mathematics performance in grade eight? If between school-type tracking has taken place before the mathematics test is administered, it is likely that children of different social backgrounds have been enrolled in different types of education at the moment of testing, with different levels of mathematics classes. Because of the structural location that is caused by social differences in myopia, information quality and educational aspirations, children of disadvantaged backgrounds are likely to be enrolled in lower tracks, whereas advantaged students are more likely to enrol in the higher tracks. It is thus to be expected that inequalities by social origin in mathematics achievement are reduced in comprehensive educational systems compared to early-tracking systems particularly because the allocation of students to tracks is affected by social background (Dronkers et al. 2012; Le Donné 2014b).

Improvements of equality of opportunity may come at a cost in the form of lower performances. Inequalities may bring a shock to the educational system that affects teachers, schools and students, which could lead to a reduction in student performance. The consequences of comprehensive reforms may particularly affect the high-achievers, as they are generally thought to be kept back by reforms.

\section{RESEARCH DESIGN}

\section{Describing the explanandum}

A first descriptive empirical analysis replicates existing studies showing larger inequalities in systems with early tracking, for a large number of countries. We present this descriptive evidence as

pointing to the explanandum: Considering a large number of countries, we see larger inequalities by 
social background if tracking happens earlier in the school career. Figure 1 shows the crosssectional relationship between the age of selection in educational systems, and inequality of educational opportunity. This is done with the data of the Programme for International Student Assessment (PISA) of 2009.

We use parental socio-economic status (SES, measured by the Economic and Social-Cultural Status index that is provided with the PISA data, a measure consisting of parental education, occupation and various resources). The used SES scale takes the proportional value within countries (theoretical minimum 0, maximum 1). Mathematics achievement is standardized as a z-score across countries.

[Figure 1 about here]

Figure 1 shows the level of inequality by social origin in mathematics achievement on the y-axis, assessed by the OLS regression coefficient of socioeconomic status predicting mathematics achievement. On the horizontal axis countries are placed according to the age at which students are selected into different school types, ranging from 10 in Germany and Austria, to sixteen in all Scandinavian and Anglo-Saxon countries. This information is obtained from the OECD (2005). The general descriptive pattern is clear: inequality of educational opportunity is larger in societies where students are separated relatively early. It is also evident that there is scatter around the least squares regression line, indicating substantial variability in inequality levels among countries with the same age of selection. Other research has demonstrated that the association between tracking and inequality upholds after controlling for other relevant variables, including the size of the private education sector, the vocational orientation of the educational system, government expenditure on education, and GDP per capita (see Bol and Van de Werfhorst 2013). It should also be emphasized that, even though early tracking is related to higher levels of inequality, a potential advantage of 
early-tracking systems is that early tracking (or especially a strong vocational orientation) promotes access of young graduates to the labor market.

\section{The Comparative Reform Design}

Because most of the reforms took place in an era in which equal opportunities were highly salient in the public and political debates, we can analyze the association between reforms of tracking age and standardized student assessment. A few countries have reformed the educational system into comprehensive education in between the two first international student assessments of

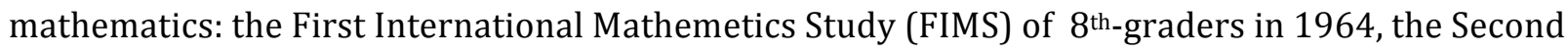

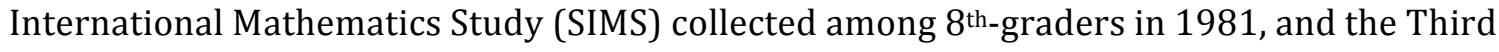
International Mathematics and Science Study (TIMSS) collected among $8^{\text {th }}$-graders in $1995 .{ }^{1}$ In total, student-level data are available on nine countries that participated in both assessments. Table 1 shows, for each of the nine countries, whether their educational system was comprehensive or tracked for the grade- 8 students. Finland, France, England and Scotland have reformed their educational systems between 1964 and 1981, whereas the Netherlands and Belgium have retained a tracked educational system. ${ }^{2}$ Three further countries have retained their comprehensive system throughout the observation period, Japan, Israel and the United States.

\section{[Table 1 about here]}

\footnotetext{
${ }^{1}$ These datasets are disseminated under auspices of the IEA, the International Association for the Evaluation of Educational Achievement (www.iea.nl).

2 It is acknowledged that a dummy variable representing tracked versus comprehensive forms of secondary education may not measure the effects of all forms of curriculum tracking prevalent in various educational systems. Also within schools in comprehensive systems different tracks exist that are related to various forms of inequality (Gamoran \& Mare 1989; Lucas 2001; Chmielewski 2014). Yet, we follow existing comparative research in which system-level regulations are studied concerning separate forms of education for the full curriculum, and for the duration of several years. Following the typology offered in the comparative literature the present study is mostly concerned with between-school tracking systems (LeTendre et al. 2003; Chmielewski 2014).
} 
In FIMS 1964 and SIMS 1981, mathematics achievement is measured by a standardized battery of multiple choice questions, of which the proportion that was answered correctly was taken. Plausible values were not available in the FIMS and the SIMS. In order to be able to compare the two datasets, the mathematics score was standardized across the nine countries within cohorts (see Brown et al. 2007 for a similar approach).

Parents' socioeconomic status is measured using (1) a proportional score of parents' highest educational attainment within countries and year of assessment, and father's social class (white collar versus blue collar). Father's social class was not included in the TIMSS 1995 data. The surveys used different operationalizations of parental education, and with our method of standardization the variability within the surveys is optimized while comparisons between datasets can be made. Parental education measured this way thus reflects the relative educational attainment of parents in the distribution of that country for that particular cohort.

The identification of the effect of the reform from tracked to comprehensive education on inequality of educational opportunity rests on the differences in the trend in the slopes between the countries that have changed their policy in comparison to the change in slope found in countries that have not adapted their educational system. The following fixed effects least squares model is estimated, using the same strategy as recent studies on regional variations within countries by Meghir and Palme (2005) and Pekkarinen et al. (2009):

$\mathrm{y}_{i t c}=\beta_{0}+\beta_{1} \mathrm{~T}_{\mathrm{t}}+\beta^{\prime}{ }_{2} \mathrm{C}_{\mathrm{c}}+\delta \cdot \operatorname{COMP}_{t c}+\gamma \cdot S E S_{i t c}+\eta \cdot S E S_{i t c} \cdot C_{c}+\lambda \cdot S E S_{i t c} \cdot C O M P_{t c}+\varepsilon_{i t c}$

With $y_{i t c}$ being the standardized mathematics test score for individual $i$ for cohort $t$ in society $c$. The $\beta_{1}$ parameter is a fixed effect for year (T), the $\beta_{2}^{\prime}$ parameters indicate fixed effects for societies $\mathrm{C}$ (countries). COMP is a dummy variable with the value of 1 for children in a society and wave with 
comprehensive education, and 0 for children in a society and wave in which there is a tracked educational system. The $\delta$-parameter is the overall effect of comprehensive education on achievement (given the included interaction term with parents' SES this effect reflects the effect for students with parents' SES being 0, i.e. a low parental educational level and a non-white-collar class background). The $\gamma$-parameter reflects the effect of parents' educational level on math performance, for tracked educational systems. The $\eta$-parameter provides baseline country differences in the slope of socioeconomic background. The $\lambda$-parameter is the difference-in-difference estimate of the effect of comprehensive education reform on the effect of parents' SES (for different SES indicators, parents' education and father's occupation). To illustrate this, the predicted mathematics score can be calculated for the two cohorts for country types. For countries that have retained their tracked system the difference in the predicted math score, for a given level of education of the parents, between two cohorts is equal to $\beta_{1}$. For countries that have reformed from a tracked to a comprehensive system, the difference between two cohorts is equal to $\beta_{1}+\delta+\lambda \cdot S E S$. The difference-in-difference is thus represented by $\delta+\lambda \cdot S E S$. The residual variance is identified with $\varepsilon_{i t c .}$

The model of equation (1) is estimated as a least squares model on the mean performance, and as quantile regressions on the $15^{\text {th }}, 50^{\text {th }}$, and $85^{\text {th }}$ percentile. Quantile regressions enable us to estimate the relation between reforms and social inequalities in performance in different parts of the distribution of mathematics achievement. There are two different ways to estimate quantile regression, with very different conceptual understandings of the distribution that is examined: conditional and unconditional quantile regression models (Killewald and Bearak 2014). We are particularly interested in the relationship between tracking and social inequality in low performance and in high performance, thereby focusing on the different parts in the distribution of 
the original mathematics performance score, obtained from the unconditional quantile regression model..$^{3}$

It should be noted that our study, like much of the comparative literature, is concerned with between-school tracking; a form of tracking that most clearly varies between educational systems, but which conceals important within-school tracking practices associated to inequalities (Lucas 2001; Gamoran and Mare 1989: Marks 2013). Within-school tracking is found to magnify differences between students in terms of subjective educational outcomes including self-efficacy and study involvement, because students in heterogeneous schools compare themselves to other peers than students in homogeneous schools (Chmielewski et al. 2013; Van Houtte and Stevens 2009). Nevertheless, given that there is such a clear pattern of association between the level of between-school tracking and inequalities, within-school tracking practices do not create similar inequalities as between-school tracking systems do (Chmielewski 2014).

\section{Two relevant assumptions}

Difference-in-difference models allow us to identify the effect of comprehensive education on the basis of a relevant assumption. The common trends assumption holds that, in the absence of a 'treatment' towards comprehensive education, the difference in inequality by social origin between two moments in time (cohorts or grades) for the treatment group would have been identical to the difference in the control group (Angrist and Pischke 2009). So it is assumed that the trend in social inequality in systems that have transformed their educational system towards comprehensive education would have been the same as the trend in systems that have not reformed their educational system. The assumption has two implications: (1) the reform towards comprehensive education is assumed to be the only aspect that changed in educational systems between 1964 and

\footnotetext{
3 We use the rifreg command in Stata for this, developed by Firpo et al. (2009).
} 
1981, (2) reforms are exogenous to existing levels of inequality, egalitarian public opinion and politics.

The parallel trends assumption is too strong to be fully determined about the causality of comprehensive reform on inequality. Yet, as described above, policies to reform educational systems to improve opportunities for children of lower social class origins were set in place almost everywhere, also in the countries that have retained a tracked system (the Netherlands and Belgium). In all of the studied societies educational policies in the 1960s and 1970s were strongly inspired by an egalitarian agenda. However, arguably the most significant difference between the countries is whether reforms have included the abolishment of tracked secondary education in favour of comprehensive schooling.

[Table 2 here]

In order to shed some light on possible confounding factors related to egalitarian climate differences between reformed and unreformed countries, which form a potential alternative explanation for country differences, some evidence is displayed in table 2 . In the top panel of table 2 a logistic regression model is estimated predicting the odds of favouring equality over freedom among the public. ${ }^{4}$ Using the European Values Study / World Values Study of $1981^{5}$, the earliest available comparative dataset on egalitarian attitudes, we see that there are country differences. Yet, there is no systematic variation in relation to the educational system. It is not the case that people had more egalitarian ideals in countries where reforms have been implemented. In fact, if

${ }^{4}$ The exact question wording is: "Which of these two statements comes closest to your own opinion? A. I find that both freedom and equality are important. But if I were to choose one or the other, I would consider personal freedom more important, that is, everyone can live in freedom and develop without hinderance; B. Certainly both freedom and equality are important. But if I were to choose one or the other, I would consider equality more important, that is, that nobody is underprivileged and that social class differences are not so strong." (answer categories: Freedom above equality, neither (both coded 0), equality above freedom (coded 1).

5 Unfortunately Finland did not take part in the first wave of the EVS, so we took the second wave instead for Finland (1990). 
the six countries are categorized with regard to the comprehensive education system, comprehensive countries had a slightly lower priority for equality over freedom (model 2). This pertains after holding constant for net income inequality in a country (model 3).

Another piece of information relates to the factual level of income inequality in societies. The Gini-coefficients measuring net household income inequality taken from Solt (2009) show that inequality has declined between the 1960 and 1980 in some countries (France, Finland, the Netherlands), but risen in others (United States, Israel). However, neither inequality nor the decline in inequality during the assessment period, seem to be related to whether educational reforms have been implemented. If anything, there is some evidence of the opposite, with hardly any decline in income inequality in the United Kingdom, and a weaker decline in another reformed country (France) relative to an unreformed country (Netherlands). Finally, neither the political partisanship of governments, here indicated by the party of the prime minister, is pointing towards a more leftwing government in the 1960s in reformed countries. Judged by the prime minister's political color, conservative parties were strong in both the 1960s and the 1980s, although the rise of social democracy in Finland can be observed.

All in all, these pieces of circumstantial evidence indicate no systematic relationship in the nine countries that we study between the implementation of reforms and an egalitarian ideology, an egalitarian income distribution, or stronger power of left-wing governments. Also in unreformed countries an egalitarian ideology emerged in the time window of observation, which, most clearly in the Netherlands, led to other educational reforms that promoted the 'stacking' of different types of education, rather than reducing the tracked nature of the system. The presented evidence does not guarantee that the impact of reforms on inequality in educational achievement is causal, but it makes it worthwhile to examine the relationship between tracking age reforms and student test scores using a comparative policy reform design. 
The second relevant assumption is that the mathematics tests at different moments in time need to be comparable, and assesses an underlying dimension with comparable validity and reliability. Comparability is optimized by standardizing the mathematics score within assessment years across countries (see Brown et al. 2007 for a similar way of standardization). Because only countries are included that were available at both cohorts or both grades, this way of standardization means that the difference in difference relates to the within-assessment distribution.

\section{RESULTS}

We run several models on student achievement, with different subsets of the data. Most of the models use data from the FIMS and SIMS only, as all reforms in the countries of investigation have taken place in between these two first student assessments (at least not after 1981), and because both indicators of socioeconomic background are available in these data. Table 3 shows the results of nine regression models.

Model 1 shows, not surprisingly, a strong positive association between parents' educational level and math performance. Across the maximum range of the parental educational distribution, the math performance varies by 0.7 standard deviations. Father's social class is, on top of that, also strongly associated to performance; children of white collar workers outperform children of bluecollar workers by 0.35 standard deviations, even among children with similar parental education levels. Male students score higher on the math test than female students. Models 1 and 2 also show that inequality by social origin gets relatively weaker in countries that have reformed their educational system towards comprehensive education. Model 1 shows that the social class differences get reduced in reformed systems, while model 2 finds stronger support for the decline in the slope of parental education. Models 4 and 5 look at social class and parents' education 
separately, and the results are in line with the hypothesis that comprehensive reforms have reduced inequalities by social origin. However, if the longer term trend is analyzed in model 3 , that uses data from two post-reform waves (1981 and 1995), no decline is found in the effect of parental education. So while we find support for declining inequalities by social origin in countries that have postponed their moment of selection, we do not find support for longer-term effects as well. Also if we only analyze countries that started off with a tracked system (model 6) we find support for reduced inequalities in reformed systems.

Then, as robustness checks, the last three models each leave out one country, for different reasons. Model 7 estimates the model without the French data, as the post-reform data of 1981 are collected right after the reform took place. Model 8 omits England because our results indicated that the decline in inequality between 1965 and 1981 was particularly steep in the English data. Model 9 leaves out Israel because Postlethwaite (1967) mentioned sampling problems in the Israeli data of 1964. Concerning the impact of social class, the robustness checks are consistent with the hypothesis that early tracking creates inequalities by social background. However, with regard to parents' education we do not find support for idea that postponing tracking would reduce inequalities. These results confirm that the study of inequalities in education should examine multiple indicators of social origin. The more consistent findings with regard to parental social class may illustrate that parents more easily adjust the educational strategies for their children if they have obtained higher levels of schooling than if they work in white-collar jobs per se.

The difference-in-difference estimate of the main effect of comprehensive education is negative, consistently across models. This finding indicates that comprehensive education may have a negative impact on the performance of children. This goes against the findings of the regional comparisons in Sweden and Finland, where no effects of comprehensive education on student performance were found (Meghir and Palme 2005; Pekkarinen et al. 2009). It also points to a trade- 
off between equality of opportunity and efficiency in the educational system. Larger equalities by social backgrounds were achieved with the costs of lower average performance.

[Table 3 about here]

The results of this first difference-in-difference analysis are also summarized in figure 2 . The clearest reduction in the slope of parental background is found in systems that have moved from a tracked to a comprehensive system.

[Figure 2 about here]

\section{Inequalities at the bottom and the top of the mathematics distribution}

To further investigate the relationship between reforms and inequality of educational opportunity, unconditional quantile regression models are estimated for the bottom $\left(15^{\text {th }}\right.$ percentile of the international distribution) and the top (85 ${ }^{\text {th }}$ percentile of the international distribution). We also estimate the median score $\left(50^{\text {th }}\right.$ percentile), as a comparison to the means regression models above. Table 4 shows the results.

The first column shows that there is not the expected reduction in social inequality in poor performance in relation to a postponement of the moment of selection. On the contrary, we see larger inequalities among poorly performing students in systems that have reformed their system towards comprehensive education. The results with regard to the median (column 2) are similar to model 1 of table 3 - a reform to later tracking reduces the inequality by father's social class, but not by parents' education. The statistical effects are even stronger for the top of the distribution

(column 3 in table 4); comprehensive education is particularly associated to a reduction in top 
performance. Children of the working class can more easily reach high achievement in comprehensive systems. Children of lower educated backgrounds do not see the same advantage concerning the avoidance of low-performance. Comprehensive education thus more easily reduces inequality at the top of the distribution, by making high performance more easily reachable for disadvantaged children. It does not reduce inequalities in who performs poorly - in fact our results indicate that inequality in low performance gets higher with the introduction of comprehensive reforms.

Looking at the main effect of comprehensive education, we see that the trade-off between equal opportunities and efficient learning only emerges at the middle of the distribution. Only at the $50^{\text {th }}$ percentile we see that reduced inequalities by father's social class coincide with reduced performance. At the $15^{\text {th }}$ percentile we also see a reduction in performance after the reform, but there there the other part of the trade-off is not found (no reduced inequality). At the top of the distribution (85th percentile) there is also not a trade-off between equal opportunities and efficiency, as there is hardly any loss in the top performance after the reform. Thus, to the extent that a trade-off emerges, it is not because bright children are held back by putting them in comprehensive schools.

[Table 4 about here]

\section{CONCLUSIONS AND DISCUSSION}

This paper showed that inequality of educational opportunity, measured by the association between parents' socioeconomic status and student performance on standardized mathematics tests, is larger in tracked educational systems than it is in comprehensive systems. Using a difference-indifference design, this study was able to study the relationship between policy reforms towards 
comprehensive education and inequality of educational opportunity. By exploiting evidence on reforms towards tracking children for different educational careers at a later grade that happened in the 1960 s and 1970 s, we can inform contemporary debates about early selection in many societies. The Prime Minister of the United Kingdom Theresa May has announced in 2016 that she wants to re-establish the English grammar schools - reverting the English reform to comprehensive education. In Belgian Flanders a reform has been proposed early 2017 that will reduce the rigidity of early selection. In the Netherlands, early selection has been put on the political agenda by the Dutch Inspectorate of Education in 2016. American education experts fear that the Trump administration may enlarge segregation between public and charter schools. What can we learn from past reforms about the reduction of inequality that is associated to comprehensive education aimed at social inclusion?

This study assessed to what extent social inequality changed in countries that have reformed their educational structure from a tracked to a comprehensive system, compared to the change in countries that have retained their tracked nature. International student assessments of 1964, 1981 and 1995 have been used for this study. The results provide evidence for the hypothesis that comprehensive education reduces inequalities by social origin. In societies that have reformed their educational system, inequality by social origin substantially reduced between 1964 and 1981. So, whereas earlier research has mostly studied cross-sectional data on student performance, which makes it difficult to assess the effect of comprehensive education on inequality of educational opportunity, this study confirmed that equal opportunities are harmed by the separation of students into distinct tracks.

However, the inequality-reducing effects of later tracking are much more variable than earlier studies acknowledged. First of all, we found much stronger evidence for a reduction in the association between father's social class and mathematics achievement than between parents' educational attainment and achievement. Comprehensive education is more easily able to be 
inclusive of working class children than to be inclusive of children of low-educated backgrounds. One tentative explanation for this finding is that educated parents can keep up their advantage in adapted systems more easily. Another is that parental education is, in a multivariate model as employed here, more indicative of intergenerationally transmissible talents that are hard to address with policies. Second, the inequality reduction was most pronounced at the top of the mathematics distribution, and absent at the bottom of the distribution. Earlier studies have often suggested that comprehensive education was able to be inclusive for the low-achievers. The current results show rather that comprehensive education makes a high level of achievement more easily reachable for working class children.

The current study is also able to address a possible trade-off between equal opportunities and efficient learning. Does a reduction of inequality come at a cost of declining performance? We found evidence for a trade-off, but again here the results are more nuanced than previous research found. It appeared that a reform towards comprehensive education reduced inequalities between students of different social backgrounds, but also reduced the average performance of students. Plausibly reforms bring a shock to school processes leading to lower performances. Importantly, however, the decline in performance after reforms was most evident at the middle and the bottom of the mathematics distribution, but was not found at the top of the distribution. That is relevant as one important argument against comprehensive education, invalidated by our results, is that it would keep the high-performers back.

\section{Literature}

Angrist, J. D., \& Pischke, J.-S. (2009). Mostly Harmless Econometrics. An Empiricist's Companion. Princeton: Princeton University Press.

Blossfeld, H.-P., \& Shavit, Y. (1993). Persisting Barriers. Changes in Educational Opportunities in Thirteen Countries. In Y. Shavit \& H.-P. Blossfeld (Red.), Persistent Inequality. A Comparative Study of Educational Attainment in Thirteen Countries (pp. 1-23). Boulder, C0: Westview Press. 
Bol, Thijs, en Van de Werfhorst, Herman G. (2013). Educational Systems and the Trade-off Between Labor Market Allocation and Equality of Educational Opportunity. Comparative Education Review, 57(2): 285-308.

Boliver, V., \& Swift, A. (2011). Do comprehensive schools reduce social mobility? The British Journal of Sociology, 62(1), 89-110.

Breen, R., \& Goldthorpe, J. H. (1997). Explaining Educational Differentials: Towards a Formal Rational Action Theory. Rationality \& Society, 9, 275-305.

Brown, G., Micklewright, J., Schnepf, S. V., \& Waldmann, R. (2007). International surveys of educational achievement: how robust are the findings? Journal of the Royal Statistical Society: Series A (Statistics in Society), 170(3), 623-646.

Brunello, G., \& Checchi, D. (2007). Does school tracking affect equality of opportunity? New international evidence. Economic Policy, 22(52), 781-861.

Buchmann, C., \& Park, H. (2009). Stratification and the formation of expectations in highly differentiated educational systems. Research in Social Stratification and Mobility, 27(4), 245-267. https://doi.org/10.1016/j.rssm.2009.10.003

Chmielewski, A. K. (2014). An International Comparison of Achievement Inequality in Withinand Between-School Tracking Systems. American Journal of Education, 120(3), 293324.

Chmielewski, A. K., Dumont, H., \& Trautwein, U. (2013). Tracking Effects Depend on Tracking Type: An International Comparison of Students' Mathematics Self-Concept. American Educational Research Journal, 50(5), 925-957. Cobb-Clark, D. A., Sinning, M., \& Stillman, S. (2012). Migrant Youths' Educational Achievement The Role of Institutions. The ANNALS of the American Academy of Political and Social Science, 643(1), 18-45.

Dronkers, J. (1993). Educational Reform in the Netherlands: Did It Change the Impact of Parental Occupation and Education? Sociology of Education, 66(4), 262-277.

Dronkers, J., Van Der Velden, R., \& Dunne, A. (2012). Why are Migrant Students Better Off in Certain Types of Educational Systems or Schools than in Others? European Educational Research Journal, 11(1), 11-44.

Duru-Bellat, M., \& Kieffer, A. (2000). Inequalities in educational opportunities in France: educational expansion, democratization or shifting barriers? Journal of Education Policy, 15(3), 333-352.

Duru-Bellat, M., \& Mingat, A. (1990). How do French junior secondary schools operate? Academic achievement, grading, and streaming of students. In A. Leschinsky \& K. U. Mayer (Red.), The comprehensive school experiment revisited: Evidence from Western Europe (pp. 62-91). Frankfurt: Peter Lang.

Duru-Bellat, M., \& Suchaut, B. (2005). Organisation and Context, Efficiency and Equity of Educational Systems: what PISA tells us. European Educational Research Journal, 4(3), 181-194.

Erikson, R., \& Jonsson, J. O. (1996). Explaining Class Inequality in Education: The Swedish Test Case. In R. Erikson \& J. O. Jonsson (Red.), Can Education be Equalized? The Swedish Case in Comparative Perspective (pp. 1-63). Boulder, C0: Westview Press.

Firpo, S., Fortin, N. M., \& Lemieux, T. (2009). Unconditional Quantile Regressions. Econometrica, 77(3), 953-973.

Gamoran, A. (1996). Curriculum Standardization and Equality of Opportunity in Scottish Secondary Education: 1984-90. Sociology of Education, 69, 1-21. 
Gamoran, A., \& Mare, R. D. (1989). Secondary School Tracking and Educational Inequality: Compensation, Reinforcement, or Neutrality? American Journal of Sociology, 94(5), 11461183.

Gamoran, A., \& Weinstein, M. (1998). Differentiation and Opportunity in Restructured Schools. American Journal of Education, 106(3), 385-415.

Halsey, A. H., Heath, A. F., \& Ridge, J. M. (1980). Origins and Destinations: Family, Class, and Education in Modern Britain. Oxford: Clarendon Press.

Hanushek, E. A., \& Wössmann, L. (2005). Does Educational Tracking Affect Performance and Inequality? Differences-in-Differences Evidence Across Countries. Economic Journal, 116, C63-C76.

Hanushek, E. A., \& Woessmann, L. (2011). The Economics of International Differences in Educational Achievement. In E. A. Hanushek, S. Machin, \& L. Woessmann (Red.), Handbook in the Economics of Education (Vol. 3, pp. 89-200). The Netherlands: North-Holland/Elsevier.

Heath, A. F. (1990). Educational reform and changes in the stratification process in Great Britain. In A. Leschinsky \& K. U. Mayer (Red.), The comprehensive school experiment revisited: Evidence from Western Europe (pp. 92-110). Frankfurt: Peter Lang.

Jackson, M., Jonsson, J. O., \& Rudolphi, F. (2012). Ethnic Inequality in Choice-driven Education Systems A Longitudinal Study of Performance and Choice in England and Sweden. Sociology of Education, 85(2), 158-178.

Kelly, S., \& Price, H. (2011). The Correlates of Tracking Policy Opportunity Hoarding, Status Competition, or a Technical-Functional Explanation? American Educational Research Journal, 48(3), 560-585.

Killewald, A., \& Bearak, J. (2014). Is the Motherhood Penalty Larger for Low-Wage Women? A Comment on Quantile Regression. American Sociological Review, 79(2), 350-357.

Lavrijsen, J., \& Nicaise, I. (2015). New empirical evidence on the effect of educational tracking on social inequalities in reading achievement. European Educational Research Journal, 14(3-4), 206-221.

Le Donné, N. (2014b). La réforme de 1999 du système éducatif polonais. Effets sur les inégalités sociales de compétences scolaires. Revue française de sociologie, 55(1), 127-162.

Le Donné, N. (2014a). European Variations in Socioeconomic Inequalities in Students' Cognitive Achievement: The Role of Educational Policies. European Sociological Review, 30(3), 329343.

LeTendre, G. K., Hofer, B. K., \& Shimizu, H. (2003). What Is Tracking? Cultural Expectations in the United States, Germany, and Japan. American Educational Research Journal, 40(1), 43-89.

Lucas, S. R. (2001). Effectively Maintained Inequality: Education Transitions, Track Mobility, and Social Background Effects. American Journal of Sociology, 106(6), 1642-1690. doi:10.1086/321300

Marks, G. N. (2005). Cross-national differences and accounting for social class inequalities in education. International Sociology, 20(4), 483-505.

Marks, G. N. (2013). Evaluating Effectively Maintained Inequality: School and post-school transitions, socioeconomic background, academic ability and curricular placement. Social Science Research, 42(6), 1635-1649. 
Meghir, C., \& Palme, M. (2005). Educational Reform, Ability, and Family Background. The American Economic Review, 95(1), 414-424.

Montt, G. (2011). Cross-national Differences in Educational Achievement Inequality. Sociology of Education, 84(1), 49-68.

Morgan, S. L. (2005). On the Edge of Commitment: Educational Attainment and Race in the United States. Stanford, CA: Stanford University Press.

OECD (Organization for Economic Cooperation and Development). 2005. Education at a Glance, 2005. Paris: OECD.

Parker, P. D., Jerrim, J., Schoon, I., \& Marsh, H. W. (2016). A Multination Study of Socioeconomic Inequality in Expectations for Progression to Higher Education: The Role of Between-School Tracking and Ability Stratification. American Educational Research Journal, 53(1), 6-32.

Pekkarinen, T., Uusitalo, R., \& Kerr, S. P. (2009). School Tracking and Development of Cognitive Skills. SSRN eLibrary. http://papers.ssrn.com/sol3/papers.cfm?abstract_id=1369804

Postlethwaite, N. (1967). School organization and student achievement. A study based on achievement in mathematics in twelve countries. Uppsala: Almqvist \& Wiksell.

Prost, A. (1990). Schooling and social stratification: Paradoxes of the Reform of the middle school in 20th-century France. In A. Leschinsky \& K. U. Mayer (Red.), The comprehensive school experiment revisited: Evidence from Western Europe (pp. 38-61). Frankfurt: Peter Lang.

Ruhose, J., \& Schwerdt, G. (2016). Does early educational tracking increase migrant-native achievement gaps? Differences-in-differences evidence across countries. Economics of Education Review, 52, 134-154.

Schütz, G., Ursprung, H., \& Wössmann, L. (2008). Education policy and equality of opportunity. Kyklos, 61(2), 279-308.

Solt, F. (2009). Standardizing the World Income Inequality Database. Social Science Quarterly, 90(2), 231-242.

Van de Werfhorst, H.G., \& Mijs, J.J.B. (2010). Achievement Inequality and the Institutional Structure of Educational Systems: A Comparative Perspective. Annual Review of Sociology, 36, 407428.

Van Houtte, M., \& Stevens, P. A. J. (2009). Study Involvement of Academic and Vocational Students: Does Between-School Tracking Sharpen the Difference? American Educational Research Journal, 46(4), 943-973.

Willms, J. D. (1986). Social Class Segregation and Its Relationship to Pupils' Examination Results in Scotland. American Sociological Review, 51(2), 224-241. 


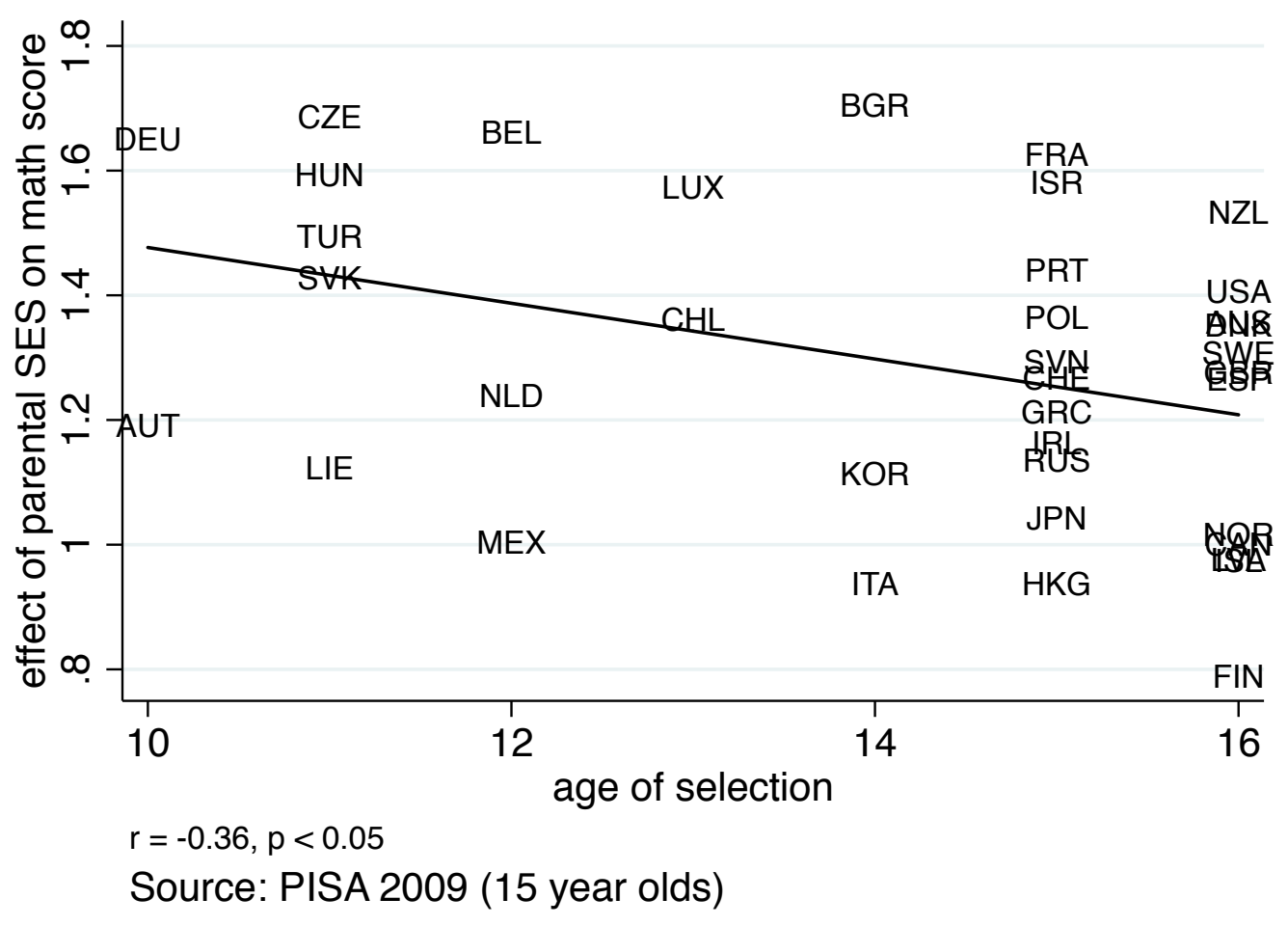

Figure 1: inequality in mathematics achievement by social origin, by age of selection in the educational system 

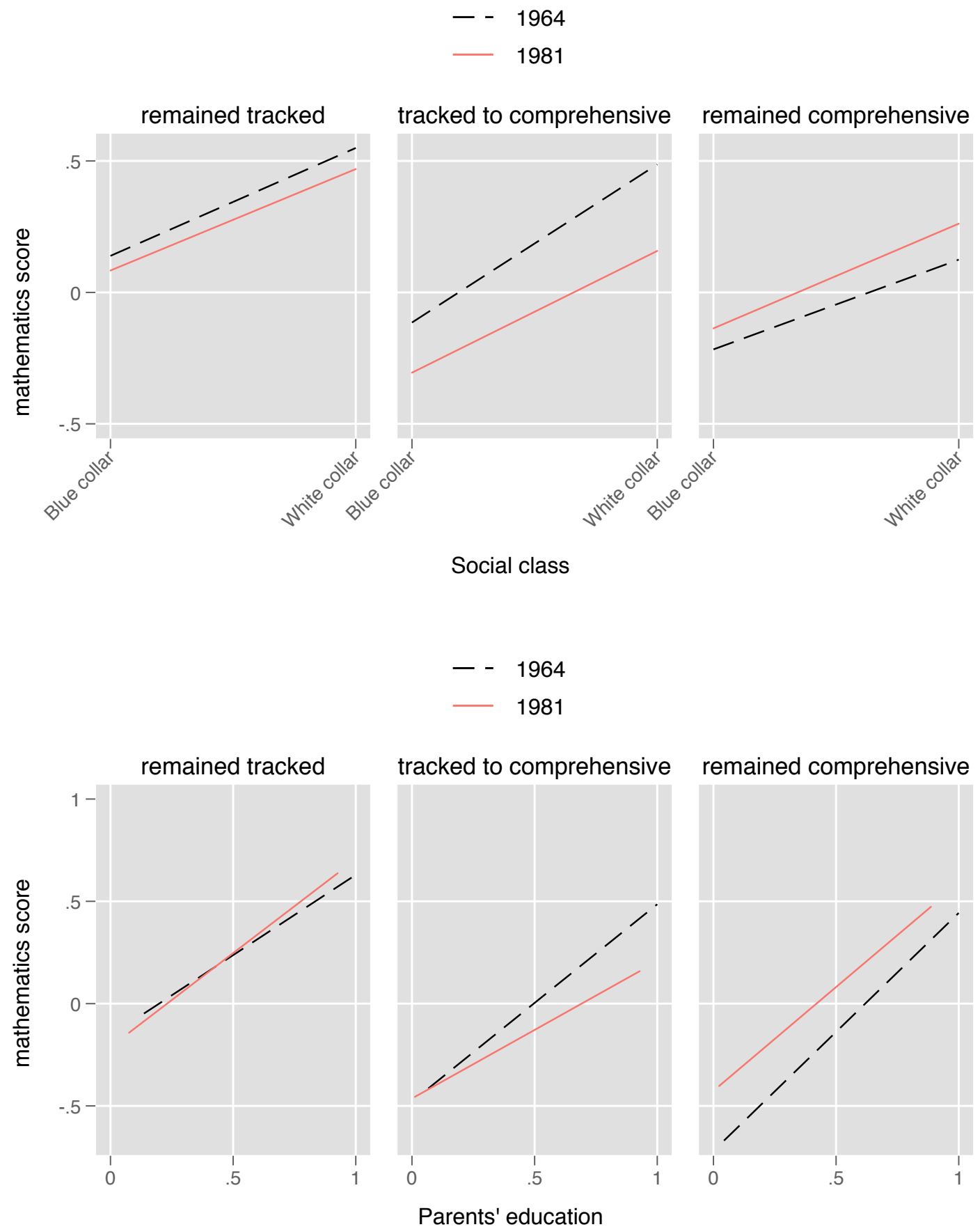

Figure 2: Associations between father's class and parents' education and average mathematics achievement, based on model 2 , table 3 
Table 1: Tracked or comprehensive secondary education in each assessment year

\begin{tabular}{|c|c|c|c|c|c|}
\hline \multirow[b]{2}{*}{ Country } & \multicolumn{3}{|c|}{ year } & \multirow[b]{2}{*}{ Total N } & \multirow[b]{2}{*}{ Year of reform } \\
\hline & 1964 & $1981 / 82$ & 1995 & & \\
\hline Belgium & tracked & tracked & tracked & 14,537 & \\
\hline England \& Wales & tracked & comprehensive & & 7,788 & 1970 \\
\hline Finland & tracked & comprehensive & & 5,410 & 1975 \\
\hline France & tracked & comprehensive & comprehensive & 17,393 & 1980 \\
\hline Israel & comprehensive & comprehensive & comprehensive & 7,146 & \\
\hline Japan & comprehensive & comprehensive & & 5,935 & \\
\hline Netherlands & tracked & tracked & tracked & 10,824 & \\
\hline Scotland & tracked & comprehensive & comprehensive & 15,598 & 1965 \\
\hline United States & comprehensive & comprehensive & comprehensive & 26,364 & \\
\hline Total N & 36,604 & 36,000 & 38,391 & 110,995 & \\
\hline
\end{tabular}


Table 2: Endogeneity checks of reform and non-reform countries

\begin{tabular}{|c|c|c|c|c|c|c|}
\hline \multirow[t]{2}{*}{ Equality before freedom } & \multicolumn{2}{|c|}{ (1) } & \multicolumn{2}{|c|}{ (2) } & \multicolumn{2}{|c|}{ (3) } \\
\hline & $\begin{array}{l}\text { Logit } \\
\text { coefficient }\end{array}$ & Robust s.e. & $\begin{array}{l}\text { Logit } \\
\text { coefficient }\end{array}$ & Robust s.e. & $\begin{array}{l}\text { Logit } \\
\text { coefficient }\end{array}$ & Robust s.e. \\
\hline \multicolumn{7}{|l|}{ Country (relative to Belgium) } \\
\hline Great Britain & $-0.345 * * *$ & $(0.000)$ & & & & \\
\hline France & $0.151^{* * *}$ & $(0.000)$ & & & & \\
\hline Finland & $-0.586 * * *$ & $(0.000)$ & & & & \\
\hline Netherlands & $0.204^{* * *}$ & $(0.000)$ & & & & \\
\hline United States & $-0.308 * * *$ & $(0.000)$ & & & & \\
\hline Comprehensive schooling system & & & $-0.341^{*}$ & $(0.142)$ & $-0.540 * * *$ & $(0.086)$ \\
\hline Gini coefficient net household income inequality & & & & & 0.043 & $(0.024)$ \\
\hline Constant & $-0.768 * * *$ & 0 & $-0.655^{* * *}$ & $(0.078)$ & $-1.678^{* *}$ & $(0.565)$ \\
\hline $\mathrm{N}$ & 7032 & & 7032 & & 7032 & \\
\hline pseudo R-sq & 0.011 & & 0.004 & & 0.006 & \\
\hline \multicolumn{7}{|l|}{$* \mathrm{p}<0.05, * * \mathrm{p}<0.01, * * * \mathrm{p}<0.001$} \\
\hline Source: European Values Study / World Values Study 1981 & & & & & & \\
\hline
\end{tabular}

\section{Gini coefficient net household income}

Belgium (1960)

Belgium (1980)

Belgium (1995)

United Kingdom (1960)

United Kingdom (1980)

United Kingdom (1995)

France (1960)

France (1980)

France (1995)

Finland (1960)

Finland (1980)

Finland (1995)

Netherlands (1962)

Netherlands (1980)

Netherlands (1995)

Japan (1960)

Japan (1980)

Japan (1995)

Israel (1961)

Israel (1980)

Israel (1995)

United States (1960) (b)

United States (1980) (b)

United States (1995) (b)

Source: Standardized World Income Inequality Database

(a) missing data

(b) President
Prime minister's party

Christian Democrats Christian Democrats Christian Democrats Christian Democrats Conservative Conservative Gaullian Gaullian Gaullian Agrarian Party Social Democrats Social Democrats Christian Democrats Christian Democrats Social Democrats Conservative Conservative Social Democrats Social Democrats Conservative Social Democrats Republican Democrats Democrats

Source: Various 
Table 3: Fixed effects regression model on the impact of comprehensive education reform on average student achievement

\begin{tabular}{|c|c|c|c|c|c|c|c|c|c|c|c|c|c|c|c|c|c|c|}
\hline & \multicolumn{2}{|c|}{$\begin{array}{c}1) \\
\text { TO-T1 without } \\
\text { country*SES } \\
\end{array}$} & \multicolumn{2}{|c|}{$\begin{array}{c}(2) \\
\text { TO-T1 with } \\
\text { country*SES }\end{array}$} & \multicolumn{2}{|c|}{$\begin{array}{c}\text { (3) } \\
\text { T0-T1-T2 only } \\
\text { parents education }\end{array}$} & \multicolumn{2}{|c|}{$\begin{array}{c}\text { (4) } \\
\text { T0-T1 only parents } \\
\text { class } \\
\end{array}$} & \multicolumn{2}{|c|}{$\begin{array}{c}\text { (5) } \\
\text { T0-T1 only } \\
\text { parents education }\end{array}$} & \multicolumn{2}{|c|}{$\begin{array}{c}6) \\
\text { T0-T1 only initially } \\
\text { tracked systems } \\
\end{array}$} & \multicolumn{2}{|c|}{$\begin{array}{c}(7) \\
\text { T0-T1 without } \\
\text { France } \\
\end{array}$} & \multicolumn{2}{|c|}{$\begin{array}{c}(8) \\
\text { T0-T1 without } \\
\text { England } \\
\end{array}$} & \multicolumn{2}{|c|}{$\begin{array}{c}9) \\
\text { T0-T1 without } \\
\text { Israel } \\
\end{array}$} \\
\hline & $\mathrm{b}$ & $\mathrm{t}$ & $\mathrm{b}$ & $\mathrm{t}$ & $\mathrm{b}$ & $\mathrm{t}$ & $\mathrm{b}$ & $\mathrm{t}$ & $\mathrm{b}$ & $\mathrm{t}$ & $\mathrm{b}$ & $\mathrm{t}$ & $\mathrm{b}$ & $\mathrm{t}$ & $\mathrm{b}$ & $\mathrm{t}$ & $\mathrm{b}$ & $\mathrm{t}$ \\
\hline parents' education 0 - 1 & $\overline{0.695^{* * *}}$ & $(30.30)$ & $0.335^{* * *}$ & $(5.22)$ & $0.637^{* * *}$ & (19.44) & & & $0.612^{* * *}$ & $(10.90)$ & $0.321^{* * *}$ & $(4.94)$ & $0.731^{* * *}$ & $\begin{array}{l}(29.42) \\
\end{array}$ & $0.599 * * *$ & $(24.22)$ & $0.703^{* * *}$ & (30.61) \\
\hline Comprehensive education system $0 / 1$ & $-0.246 * * *$ & $(-11.48)$ & $-0.186 * * *$ & $(-6.28)$ & $-0.199 * * *$ & $(-8.02)$ & $-0.219 * * *$ & $(-12.25)$ & $-0.170^{* * *}$ & $(-5.82)$ & $-0.127^{* * *}$ & $(-3.67)$ & $-0.393 * * *$ & $(-15.97)$ & $-0.183^{* * *}$ & $(-8.05)$ & $-0.310 * * *$ & $(-14.12)$ \\
\hline Parents' education $\mathrm{x}$ comprehensive & $0.054^{\sim}$ & (1.78) & $-0.171 * *$ & $(-3.28)$ & -0.033 & $(-0.82)$ & & & $-0.166^{* * *}$ & $(-3.45)$ & $-0.170^{* *}$ & $(-3.23)$ & $0.115^{* * *}$ & $(3.49)$ & $0.175^{* * *}$ & (5.58) & -0.035 & $(-1.11)$ \\
\hline Father white collar & $0.350 * * *$ & (27.87) & $0.278^{* * *}$ & (8.20) & & & $0.364^{* * *}$ & (11.95) & & & $0.282^{* * *}$ & $(8.23)$ & $0.386^{* * *}$ & $(28.47)$ & $0.301^{* * *}$ & $(22.27)$ & $0.346^{* * *}$ & (27.49) \\
\hline White collar $\mathrm{x}$ comprehensive & $-0.125^{* * *}$ & $(-7.76)$ & $-0.050^{\sim}$ & $(-1.85)$ & & & $-0.123^{* * *}$ & $(-4.86)$ & & & $-0.049^{\sim}$ & $(-1.80)$ & $-0.160 * * *$ & $(-9.06)$ & $-0.070^{* * *}$ & $(-4.15)$ & $-0.096 * * *$ & $(-5.77)$ \\
\hline Country fixed & yes & & yes & & yes & & yes & & yes & & yes & & yes & & yes & & yes & \\
\hline Time fixed effects & yes & & yes & & yes & & yes & & yes & & yes & & yes & & yes & & yes & \\
\hline male & $0.077^{* * *}$ & $(11.10)$ & $0.079 * * *$ & $(11.37)$ & $0.077^{* * *}$ & $(13.23)$ & $0.081^{* * *}$ & $(11.37)$ & $0.079 * * *$ & $(11.54)$ & $0.117 * * *$ & $(13.32)$ & $0.065^{* * *}$ & $(8.48)$ & $0.069 * * *$ & $(9.49)$ & $0.088^{* * *}$ & $(12.13)$ \\
\hline Country $\times$ Parents' education & & & yes & & yes & & & & yes & & yes & & & & & & & \\
\hline Country $x$ White collar & & & yes & & & & yes & & & & yes & & & & & & & \\
\hline Constant & $-0.213^{* * *}$ & $(-10.92)$ & 0.002 & $(0.05)$ & -0.031 & $(-1.50)$ & $0.177^{* * *}$ & (9.19) & $-0.064^{\sim}$ & $(-1.85)$ & 0.004 & $(0.12)$ & $-0.238 * * *$ & $(-11.70)$ & $-0.137 * * *$ & $(-6.86)$ & $-0.258 * * *$ & $(-13.15)$ \\
\hline Obse & 67359 & & 67359 & & 99242 & & 67359 & & 71769 & & 42976 & & 56417 & & 60088 & & 62327 & \\
\hline R-squared & 0.175 & & 0.182 & & 0.170 & & 0.148 & & 0.170 & & 0.141 & & 0.194 & & 0.182 & & 0.171 & \\
\hline
\end{tabular}

Source: FIMS (T0), SIMS (T1), TIMSS (T2)

$\sim p<0.10, * p<0.05, * * p<0.01, * * * p<0.001$

(a) Reference country is Belgium 
Table 4: Unconditional quantile regressions for the bottom, middle and top of the international mathematics distribution

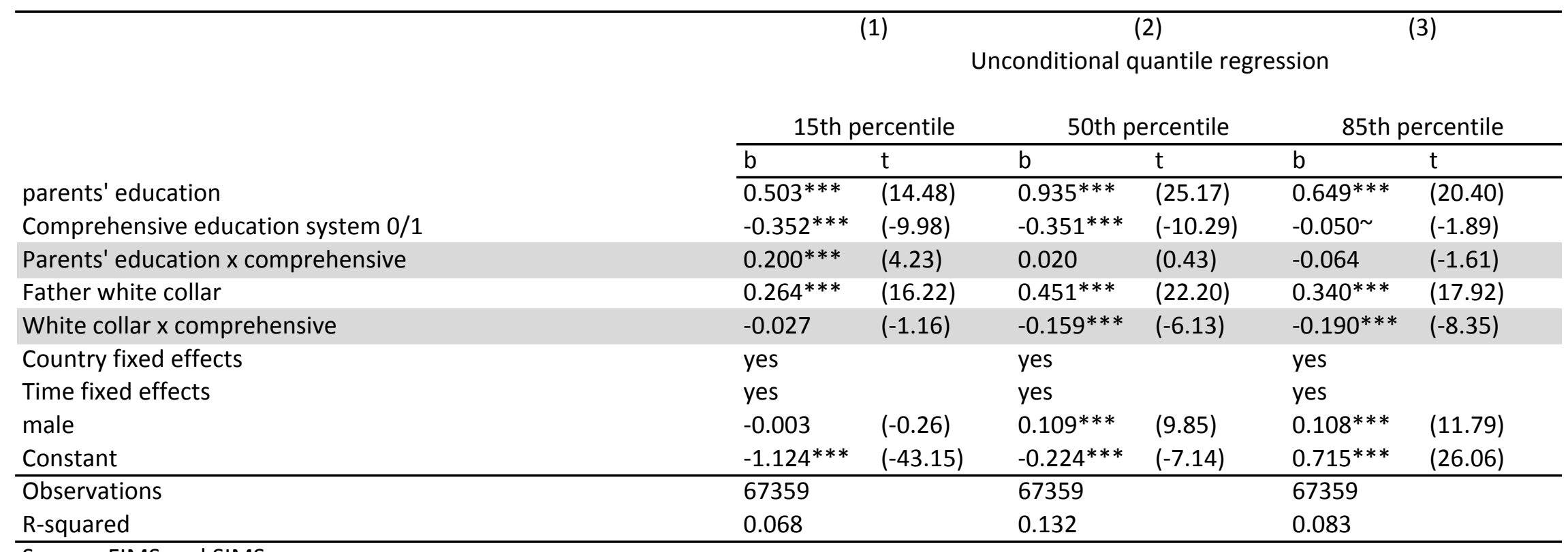

Source: FIMS and SIMS

$\sim p<0.10, * p<0.05, * * p<0.01, * * * p<0.001$ 